\title{
Kestävät ja kauniit perennat käyttöön
}

Eeva-Maria Tuhkanen ${ }^{1)}$, Terhi Suojala-Ahlfors ${ }^{1)}$, Mia Lehtinen ${ }^{2)} \&$ Sirkka Juhanoja ${ }^{1)}$

${ }^{1)}$ MTT Kasvinviljelyn tutkimus, Puutarhatuotanto, Toivonlinnantie 518, 21500 Piikkiö, eevamaria.tuhkanen@mtt.fi

${ }^{2)}$ HAMK, Puutarhatalouden ko., Lepaantie 129, 14610 Lepaa

MTT:n Puutarhatuotannolla Piikkiössä käynnistettiin vuonna 2005 hanke, joka tähtää perennojen eli monivuotisten kukkakasvien käytön laajentamiseen julkisessa viherrakentamisessa ja etsii tähän käyttötarkoitukseen sopivia perennalajeja ja hoitokäytäntöjä. Hankkeen kantavertailukokeissa vertaillaan 19 perennasuvun eri alkuperää olevien kantojen ominaisuuksia ja pyritään löytämään näistä Suomen oloihin kestävimmät ja koristearvoltaan parhaat.

Kantavertailukokeiden päämääränä on selvittää valittujen perennasukujen nimistöä, ja vertailla perennakantojen ominaisuuksia, kuten peittävyyttä, kukkimista ja koristearvoa ja taudin- ja talvenkestävyyttä parhaiden kantojen löytämiseksi ja tuotantoon saattamiseksi. Kantavertailukokeisiin valittiin sukuja, joiden ominaisuuksissa on ilmennyt kantojen välistä vaihtelua ja joiden nimistö on ollut epäselvää ja epäyhtenäistä eri taimitarhoilla. Sukujen valintaan vaikutti myös niiden mahdollinen soveltuvuus julkisille viheralueille. Kokeissa on yhteensä noin 380 kantaa kasvisuvuista Aconitum (ukonhatut), Aconogonon (röyhytattaret), Asarum (taponlehdet), Aster (asterit), Astilbe (jaloangervot), Astrantia (tähtiputket), Dicentra (pikkusydämet), Doronicum (vuohenjuuret), Eupatorium (punalatvat), Fallopia (kiertotattaret), Hosta (kuunliljat), Iris (kurjenmiekat), Nepeta (kissanmintut), Salvia (salviat) ja Thymus (ajuruohot) sekä lajeista Campanula glomerata (peurankellot), Delphinium elatum (ritarinkannukset), Geum coccineum (tulikellukat) ja Monarda didyma (punavärimintut). Kasvimateriaali hankittiin suomalaisilta perennataimistoilta, kasvitieteellisistä puutarhoista ja yksityisiltä henkilöiltä sekä siementoimittajilta. Kokeisiin saatiin siis laaja aineisto vanhoja kotimaisia kantoja, mutta myös vähän aikaa Suomessa kasvatettuja ja ulkomaisia kantoja. Vuosina 2005 - 2006 perustettiin kenttäkokeet etelään Piikkiöön ja pohjoiseen Ruukkiin, sekä Espooseen. Näissä kokeissa havainnoidaan kantojen kasvuun, kukintaan, tauteihin, tuholaisiin, koristearvoon, fenologiaan ja talvehtimiseen liittyviä ominaisuuksia. Huomiota kiinnitetään myös lajien leviämistaipumuksiin rönsyillä tai siementaimilla. Nimistön selvittämistä tehdään paitsi kasvitieteellisten ja kasvuominaisuuksien avulla, niin myös vuonna 2009 aloitettujen DNA-sormenjälkitunnistusten avulla.

Riittävän pitkäkestoiset kenttäkokeet ovat välttämättömiä, jotta viherrakennuskasvien kasvu- ja kestävyysominaisuudet saadaan luotettavasti esiin. Ainoastaan monivuotisissa kenttäkokeissa kasvit joutuvat alttiiksi riittävän vaihteleville sääoloille, ja kasvuston maksimikorkeus, leviämistaipumus tai uusimis- ja jakamistarve saadaan selville. Perennahankkeen tähänastisten tulosten perusteella jokaisesta suvusta pystytään jo erottamaan parhaat kannat talvenkestävyyden, kasvuominaisuuksien, kukinnan, tauti- ja tuholaisalttiuden tai koristearvojen suhteen. Kenttäkokeet jatkuvat vielä kasvukauden 2010, jonka jälkeen tehdään lisäykseen saatettavien kantojen lopulliset valinnat.

Asiasanat: monivuotinen koristekasvi, taksonominen tunnistaminen, talvehtiminen, viherrakentaminen 


\section{Johdanto}

Monipuolisen ja ekologisen vihersuunnittelun merkitys kasvaa kaupunkimaisen elinympäristön laajentuessa. Julkiseen viherrakentamiseen ja viheralueiden hoitoon käytettävissä olevat resurssit ovat kuitenkin vähentyneet, mikä asettaa omat haasteensa suunnittelulle (Viherympäristöliitto 2008). Viherrakentamisen kasvivalinnoilla voidaan suuresti vaikuttaa paitsi viheralueen ilmeeseen ja viihtyvyyteen, niin myös tulevaan hoidon tarpeeseen ja kustannuksiin.

Suomessa viherrakentamisen kasvivalikoimat ovat kuitenkin olleet melko suppeat, sillä viheralueilla on suosittu pääasiassa nurmikkoa, puuvartisia kasveja ja istutuksissa 1-vuotisia kukkakasveja. Perennoja eli monivuotisia kukkakasveja on käytetty lähinnä vain kaupunkien korkeimpaan hoitoluokkaan kuuluvilla alueilla. Perennat voisivat kuitenkin tarjota moneen kohteeseen helppohoitoisen, ekonomisen ja ekologisen vaihtoehdon. Perennojen laajasta lajivalikoimasta löytyy niin varjoisen kuin paahteisenkin paikan kasveja, matalia maanpeittäjiä ja korkeita, näyttäviä lajeja, aikaisin keväällä tai myöhään syksyllä kukkivia, väri- ja muotokirjoa unohtamatta. Yhdistämällä eri perennalajeja voidaankin saada näyttäviä, läpi koko kasvukauden kukoistavia ja helppohoitoisia kokonaisuuksia eri kohteisiin, kuten puistoihin, hautausmaille ja liikennealueille. Oikeilla perustamisja hoitotekniikoilla perennaistutus saattaa tarvita istutuskesän jälkeen vain 1-2 hoitokertaa kasvukaudessa, mikä helpottaisi viheralueen hoitoa esim. liikenteen jakajakaistoilla ja luiskilla, joilla lähes jokaviikkoinen nurmikonleikkuu on aikaavievää ja hankalaa työtä. Runsaampi perennojen käyttö saattaa edistää myös viheralueiden luonnon monimuotoisuutta lisäämällä esim. pölyttäjähyönteisten ja kasvinosia hajottavien maaperäeliöiden elinmahdollisuuksia.

Yhteiskunnan muutosten lisäksi ilmastonmuutos asettaa uusia haasteita viherrakentamiselle. Kasvukauden pitenemisen myötä pohjoisilla alueilla voitaneen ottaa käyttöön aikaisemmin keväällä tai myöhemmin syksyllä kukkivia lajeja. Ilmastonmuutoksen myötä kuitenkin talven- ja hallankestävyys nousee entistä ratkaisevampaan roolin kasvilajien menestymiselle pohjoisessa. Kasvukauden aikaistuminen tuo riskin halloista, joita yhä useammin saattaa esiintyä kasvun jo alettua. Talvella leudot jaksot saattavat johtaa karaistumisen ennenaikaiseen purkautumiseen, jolloin seuraavat pakkasjaksot vaurioittavat kasveja. Myös lumipeitteen puuttuminen saattaa vaikeuttaa talvehtimista. Uusien kasvitautien ja -tuholaisten leviäminen ja invaasioiden voimakkuuden muutokset täytyy myös ottaa huomioon viherrakennuskasvien tuotannossa ja vihersuunnittelussa.

Muissa maissa saadut kokemukset laajamittaisesta perennojen käytöstä (esim. Mattson 2004, Pelz 2004) ovat herättäneet mielenkiintoa myös Suomessa. MTT:n Puutarhatuotannolla Piikkiössä aloitettiinkin vuonna 2005 projekti, joka tähtää perennakasvien käytön laajentamiseen julkisessa viherrakentamisessa ja etsii tähän käyttötarkoitukseen sopivia perennalajeja ja hoitokäytäntöjä (esim. Juhanoja 2009, Juhanoja \& Lukkala 2008, Luomala ja muut 2008, Tuhkanen 2009, Tuhkanen \& Juhanoja 2009). Hanke jakaantuu käyttökokeisiin ja perennojen kantavertailukokeisiin. Käyttökokeita, joihin on valittu 150 perennalajia, on perustettu todellisiin käyttökohteisiin eri kaupunkien ja seurakuntien alueille. Näillä kokeilla etsitään sopivia lajiyhdistelmiä ja hoitokäytäntöjä erilaisiin kohteisiin, kuten esim. liikennealueiden erottajakaistoille ja jyrkille luiskille, hautausmaille ja kaupunkien puistoihin. Tässä esitellyissä kantavertailukokeissa taas vertaillaan 19 suvun eri kantojen ominaisuuksia ja pyritään löytämään niistä Suomen oloihin kestävimmät ja koristearvoltaan parhaat.

Kantavertailukokeiden päämääränä on selvittää valittujen perennasukujen nimistöä, ja vertailla perennakantojen ominaisuuksia, kuten peittävyyttä, kukkimista ja koristearvoa ja taudin- ja talvenkestävyyttä parhaiden kantojen löytämiseksi ja tuotantoon saattamiseksi. Kantavertailukokeisiin valittiin sukuja, joiden ominaisuuksissa on ilmennyt kantojen välistä vaihtelua ja joiden nimistö on ollut epäselvää ja epäyhtenäistä eri taimitarhoilla. Sukujen valintaan vaikutti myös niiden mahdollinen soveltuvuus julkisille viheralueille. Kokeissa on yhteensä noin 380 kantaa kasvisuvuista Aconitum, Aconogonon, Asarum, Aster, Astilbe, Astrantia, Dicentra, Doronicum, Eupatorium, Fallopia, Hosta, Iris, Nepeta, Salvia ja Thymus sekä lajeista Campanula glomerata, Delphinium elatum, Geum coccineum ja Monarda didyma. Kasvimateriaali hankittiin suomalaisilta perennataimistoilta, kasvitieteellisistä puutarhoista ja yksityisiltä henkilöiltä sekä siementoimittajilta. Kokeisiin saatiin siis laaja aineisto vanhoja kotimaisia kantoja, mutta myös vähän aikaa Suomessa kasvatettuja ja ulkomaisia kantoja. Vuosina 2005 - 2006 perustettiin kenttäkokeet kahdelle ilmastovyöhykkeelle, etelään Piikkiöön ja pohjoiseen Ruukkiin, sekä Espooseen. Näissä kokeissa havainnoidaan kantojen kasvuun, kukintaan, tauteihin, tuholaisiin, koristearvoon, fenologiaan ja talvehtimiseen liittyviä ominaisuuksia. Huomiota kiinnitetään myös lajien leviämistaipumuksiin rönsyillä tai siementaimilla. 
Perennakantojen nimistön selvittäminen auttaa poistamaan tuotannon päällekkäisyyksiä, ja sitä tehdään paitsi kasvitieteellisten ja kasvuominaisuuksien avulla, niin myös vuonna 2009 aloitettujen DNA-sormenjälkitunnistusten avulla.

Perennahankkeen tuloksena laaditaan julkiseen viherrakentamiseen käyttökelpoisten lajien luettelot (50-100 lajia tai kantaa) ja näille lajeille suositeltavien hoitokäytäntöjen ohjeistukset. Parhaat kannat nimetään ja saatetaan markkinoitavaksi FinE®-tuotemerkin alla. Kenttäkokeet päättyvät kasvukauden 2010 jälkeen.

\section{Aineisto ja menetelmät Koejärjestelyt ja hoito}

Kantavertailukokeisiin valittiin 19 perennakasvisukua, joiden ominaisuuksissa on ilmennyt kantojen välistä vaihtelua ja joiden nimistö on ollut epäselvää ja epäyhtenäistä eri taimitarhoilla. Sukujen valintaan vaikutti myös niiden mahdollinen soveltuvuus julkisille viheralueille. Kokeissa on yhteensä noin 380 kantaa kasvisuvuista Aconitum (14 kantaa), Aconogonon (31), Asarum (14), Aster (34), Astilbe (30), Astrantia (12), Campanula glomerata (11), Delphinium elatum (3), Dicentra (11), Doronicum (10), Eupatorium (11), Fallopia (13), Geum coccineum (8), Hosta (20), Iris (97), Monarda didyma (12), Nepeta (10), Salvia (14) ja Thymus (23). Kasvimateriaali hankittiin suomalaisilta perennataimistoilta, kasvitieteellisistä puutarhoista ja yksityisiltä henkilöiltä sekä siementoimittajilta.

Aconitum- ja Delphinium-suvut istutettiin kenttäkokeeseen Espooseen kesällä 2006. Kaikki muut suvut istutettiin kenttäkokeeseen Piikkiöön vuosina 2005 ja 2006. Suvut Aster, Astrantia, Eupatorium, Hosta, Iris, Nepeta ja Salvia istutetttiin myös Ruukkiin kesällä 2006.

Piikkiössä ja Ruukissa koekasvit istutettiin peltomaahan metrin levyisiin riveihin, joiden välissä oli lehtipuuhakkeella katetut käytävät. Espoossa käytössä oli paririvit ja Kekkilän perennamulta (Kekkilä, Tuusula, Suomi), samoin kuin Eupatorium-kokeessa Piikkiössä. Metrin levyiset rivit jaettiin $1 \mathrm{~m}^{2}$ :n kokoisiin ruutuihin, ja yhteen ruutuun istutettiin lajisuositusten mukaan 2-16 saman kannan taimea. Kookkaat tatarsuvut Aconogonon ja Fallopia istutettiin erillään oleviin $6 \mathrm{~m}^{2}: \mathrm{n}$ ruutuihin, lajisuositusten mukaisesti 9-12 taimea ruutua kohti. Kokeet toteutettiin satunnaistetuin lohkoin. Piikkiössä ja Espoossa kerranteita oli kuusi, Ruukissa kolme.

Voimakkaasti kasvullisesti leviävillä lajeilla ruudut erotettiin toisistaan $15-25 \mathrm{~cm}$ korkeilla kalvanisoiduilla pelleillä, jotka painettiin muokkauskerroksen alaosaan asti. Aconitum- ja Delphiniumkokeissa ruudut erotettiin puukehikoilla. Rönsyjen ja versojen leviämistä viereisiin ruutuihin estettin lisäksi tarpeen mukaan leikkaamalla ja kitkemällä. Myös siementaimet pyrittiin poistamaan kantojen sekoittumisen estämiseksi.

Asarum- ja Astrantia-kokeiden yläpuolelle noin 2 m:n korkeuteen rakennettiin varjostuskatos, jonka vihreä kuituverkko päästi lävitseen noin $50 \%$ auringon säteilystä. Hosta-koe jaettiin kahteen alueeseen, joista toinen oli täydessä auringonvalossa ja toinen varjostuskatoksen alla.

Piikkiössä kokeita kasteltiin sadettamalla kesällä 2005 ja tihkukastelulla vuodesta 2006 lähtien. Espoon kokeita on kasteltu sadettamalla. Piikkiössä suvut jaettiin kosteusalueeseen kunkin suvun vaatimusten mukaan. Maan kosteutta mitataan tensiometreillä, ja kastelun aloittamisen rajat eri kosteusalueilla ovat $-100 \mathrm{hPa},-150 \mathrm{hPa}$ ja $-200 \mathrm{hPa}$.

Lannoitukset ja kalkitukset tehdään maan viljavuusanalyysien perusteella. Lannoitusmäärät perustuvat Viherympäristöliiton kasvualustasuosituksiin. Piikkiön kantavertailukokeessa tehdään perus- ja syyslannoitusten lisäksi kastelulannoitusta.

Kasvitautien ja -tuholaisten kemiallista torjuntaa tehdään silloin, kun niiden vaikutuksen kasvuston seurattaviin ominaisuuksiin tai kasvuston yleiskuntoon arvellaan nousevan liian suureksi. Piikkiössä on torjuttu mm. härmää (Aster-, Monarda- ja Salvia-suvuilla), punkkeja, kuoriaisia, kaskaan nuoruusastetta, kirvoja ja myyriä. Espoossa on torjuttu kirvoja. Rikkakasveja torjutaan kitkemällä ja käytäviltä tarpeen mukaan kemiallisesti. Tuleentuneet kasvustot saavat olla paikoillaan talven yli, ja keväällä ennen kasvuunlähtöä ne silputaan ja jätetään katteeksi.

\section{Havainnot ja mittaukset}

Kasvukauden aikana havaintoja ja mittauksia tehdään kasvun alusta tuleentumisen loppuun asti. Kasvukauden säästä riippuen tämä on ollut käytännössä maaliskuun alusta jopa marraskuun alkupuolelle asti. Havainnot tehdään koeruuduittain ominaisuudesta riippuen viikon - neljän viikon 
välein. Havainnoitavat ominaisuudet liittyvät talvehtimiseen, kasvuunlähtöön, kasvun voimakkuuteen ja nopeuteen, kukintaan, tauti- ja tuholaisalttiuteen, tuleentumiseen ja koristearvoon.

Talvehtimisen onnistumista arvioidaan kasvuun lähtevien versojen määränä. Vihreänä talvehtivilla lajeilla (Asarum ja Thymus) arvioidaan myös keväällä vihreän kasvuston osuus. Kasvua arvioidaan havainnoimalla ruutua peittävän vihreän kasvuston laajuus ja mittaamalla versojen, kukkavarsien ja lehtien korkeuksia. Kukkimisen ajankohtaa ja runsautta havainnoidaan arvioimalla nuppujen ja kukkien runsaus. Kasvullista leviämistä havainnoidaan rönsyjen määrinä ja leviämistaipumuksena ruudun ulkopuolelle. Taudit ja tuholaiset pyritään tunnistamaan, ja niiden vaikutus kasvuston koristearvoon arvioidaan. Keväthallojen aiheuttamat vauriot ja niistä toipuminen tai niiden peittyminen uusien versojen alle arvioidaan. Syksyllä havainnoidaan tuleentumisen eteneminen ja mahdollinen syysväritys. Kasvuston koristearvoa arvioidaan säännöllisesti kasvukauden aikana.

\section{Tulokset ja tulosten tarkastelu}

\section{Erilaisilla kasvuominaisuuksilla ilmettä istutuksiin}

Sopivia perennalajeja ja -yhdistelmiä tiettyyn istutuspaikkaan valittaessa on otettava huomioon monia asioita. Istutuspaikan valo-olosuhteet määrittelevät, valitaanko paikalle paahteeseen soveltuvia lajeja, kuten esim. ajuruohoja (Thymus) vai varjossakin viihtyviä, kuten kuunliljoja (Hosta) tai taponlehteä (Asarum). Korkeuttakin on mietittävä: kokeissa matalimmat $\mathrm{n} .5 \mathrm{~cm}$ korkeiksi kasvavat harmaaajuruohot (T. praecox var. pseudolanuginosus) soveltuvat mainiosti liikennealueiden maanpeittäjäkasveiksi, kun taas parhaimmillaan lähes kolmimetrisiksi kasvavat punalatvat (Eupatorium) käyvät maisemallisesta elementistä avarampaankin paikkaan. Eri korkuisia, eri aikaan kukkivia ja erilaiset kasvuston muodot ja värit omaavia perennoja voidaan istutuksissa yhdistellä eri käyttötarkoituksiin sopiviksi kokonaisuuksiksi.

Kantavalintakokeissa tutkitaan perennojen ominaisuuksia kasvun nopeudesta ja voimakkuudesta kukinta-aikaan ja kestävyyteen. Samaan sukuun kuuluvien perennalajien välillä ja jopa samaan lajiin kuuluvien kantojen välillä on suurta vaihtelua, mikä toisinaan on saattanut johtaa pettymyksiin suunnittelijan tai kuluttajan saadessa kasvutavaltaan aivan erityyppisen perennan kuin on ajatellut. Esimerkiksi Thymus-suvussa monet kannat ovat talvivihreitä, ja oivia maanpeittäjäkasveja nurmikon tilalle. Vihreänäkin talvehtivien keväinen väritys poikkeaa kuitenkin suuresti toisistaan, joidenkin ollessa heleän vihreitä (esim. kangasajuruohokanta T. serpyllum 'Albus'), joidenkin taas harmahtavanmaksanpunertavia (T. praecox var. pseudolanuginosus).

\section{Ilmastonmuutos}

Ilmastonmuutoksen myötä pidentyvä kasvukausi antaa mahdollisuuden ottaa käyttöön lajeja tai kantoja, jotka eivät ole meillä aikaisemmin menestyneet. Aster-suvusta löytyy monia myöhään kukkivia syys- (A. novi-belgii) ja reunusastereita (A. dumosus -ryhmä), jotka pitkään lämpimänä jatkuneena syksynä (esim. 2009) ovat ehtineet kukkia. Syys- ja reunusastereiden kiusana on kuitenkin härmä, joka kasvukaudella 2008 monella kannalla pilasi kasvuston ja esti kukinnan lähes täysin. Myöhään kukkivia ovat myös meillä vähemmän käytetyt korkeat tuoksuasterit (A. novae-angliae), joiden eräillä kannoilla kaunis oranssinpunainen syysväritys lisää syksyistä koristearvoa. Pitkälle syksyyn kukoistavat myös esim. kissanmintut (Nepeta) ja punalatvat (Eupatorium). Aikaisin keväällä taas aloittavat kukintansa esim. vuohenjuuret (Doronicum), pikkusydämet (Dicentra) ja kurjenmiekat (Iris). Yhdistelemällä sopivia eriaikaan kukkivia lajeja saadaan istutuksen kukoistus jatkumaan toukokuulta jopa lokakuun loppuun asti.

Alkukevään lämpeneminen ja kasvuunlähdön aikaistuminen tuo kuitenkin omat riskinsä, sillä keväthallojen esiintymistodennäköisyys kasvaa. Piikkiön koekentällä erityisesti tattaret (Aconogonon ja Fallopia), pikkusydämet (Dicentra) ja jaloangervot (Astilbe) kärsivät hallavaurioista toukokuussa 2008. Alppiröyhytattaret (Aconogonon alpinum) ja kaitaröyhytattaret (A. divaricatum) olivat kestävämpiä kuin muut Aconogonon-kannat, kun taas kiertotattaret (Fallopia) saivat pahoja vaurioita. Kiertotattarien 30-40 $\mathrm{cm}$ pitkät versot kuolivat hallojen seurauksena, mutta kasvustot toipuivat ja aloittivat uuden kasvun juurista.

Keväthallojen siedon lisäksi kyky talvehtia saattaa ilmastonmuutoksen myötä nousta ratkaisevaksi perennojen menestymiselle. Talvenaikaiset lämpöjaksot saattavat johtaa karaistumisen purkautumiseen, jolloin seuraavat pakkasjaksot saattavat aiheuttaa pahoja vaurioita. Kissanminttukannat (Nepeta) ovat Piikkiössä talvehtineet hyvin, mutta Ruukissa kärsineet pahoja 
talvivaurioita. Ruukissa kissanmintuista parhaiten ovat menestyneet isolehtiset kollinminttu ( $N$. grandiflora) ja isokissanminttu (N. subsessilis).

Kasvukauden pidentymisen myötä myös lehtien koristearvon merkitys korostuu. Kurjenmiekat kukkivat lyhyen aikaa toukokuun lopulta lähtien, mutta monien kantojen lehdet tuleentuvat vasta myöhään syksyllä. Saksankurjenmiekkojen (Iris germanica) lehtien koristearvoa vähentää kuitenkin usein kesäkuun lopulta lähtien etenevä laikkutauti. Sen sijaan muutamien mätäskurjenmiekkojen (Iris graminea) ja siperiankurjenmiekkojen (Iris sibirica) rehevät kasvustot ovat vihreät ja kauniit vielä pitkälle lokakuuhun.

\section{Nimistön selventäminen}

Kantavalintakokeiden yhtenä tavoitteena on selventää kokeissa olevien perennakantojen nimistöä. Taimitarhoilla on perennojen nimistössä toisinaan epäselvyyksiä, sillä samaa kantaa saatetaan eri tarhoilla viljellä eri nimillä tai päinvastoin. Nimistön selventäminen järkeistäisi tuotantoa poistamalla tuotannon päällekkäisyyksiä. Nimistön selvittämistä ja kantojen vertailua tehdään paitsi kasvitieteellisten ja kasvuominaisuuksien avulla, niin myös vuonna 2009 aloitettujen DNAsormenjälkitunnistusten avulla. DNA-tunnistus tehdään ensin suvuista Aster, Eupatorium, Iris ja Thymus. Työ on haastavaa, sillä vertailukohtia tunnistukseen löytyy vähän, mutta DNA-sormenjälki auttaa kuitenkin kokeissa olevien kantojen joukosta tunnistamaan mahdolliset päällekkäisyydet tai epäselvyydet. Tunnistaminen palvelee samalla myös kotimaisten geenivarojen säilytystyötä, sillä monet kokeissa olevista kannoista ovat vanhoja, kulttuuriperimäksi laskettavia puutarhakasveja ja säilytettävää geenivarantoa.

\section{Johtopäätökset}

Riittävän pitkäkestoiset kenttäkokeet ovat välttämättömiä, jotta viherrakennuskasvien kasvu- ja kestävyysominaisuudet saadaan luotettavasti esiin, ja jotta tuotantoon saadaan parhaat kannat. Ainoastaan monivuotisissa kenttäkokeissa kasvit joutuvat alttiiksi riittävän vaihteleville sääoloille (vrt. leudot talvet/kovat pakkastalvet). Myöskään kasvuston maksimikorkeus, leviämistaipumus tai uusimis- ja jakamistarve eivät välttämättä käy ilmi lyhytaikaisessa kokeessa. Perennahankkeen tähänastisten tulosten perusteella jokaisesta suvusta pystytään jo erottamaan parhaat kannat talvenkestävyyden, kasvuominaisuuksien, kukinnan, tauti- ja tuholaisalttiuden tai koristearvojen suhteen. Kenttäkokeet jatkuvat vielä kasvukauden 2010, jonka jälkeen tehdään lisäykseen saatettavien kantojen lopulliset valinnat.

\section{Kiitokset}

Tätä tutkimusta ovat rahoittaneet MTT, Maa- ja metsätalousministeriö, Nikolai ja Ljudmila Borisoffin Puutarhasäätiö, Maiju ja Yrjö Rikalan Puutarhasäätiö sekä tutkimuksessa mukana olevat kaupungit ja seurakunnat.

\section{Kirjallisuus}

Juhanoja, S. 2009. Perennoilla voi koristaa monta paikkaa. Maaseudun Tiede 66:2, 13.

Juhanoja, S. \& Lukkala, R. 2008 Julkisten alueiden perennat : Väliraportti hankkeesta "Julkisten alueiden perennakasvustojen perustamis- ja hoitotekniikat sekä kestävien perennojen valinta" vuosilta 2005-2007. MTT:n selvityksiä $157.123 \mathrm{~s}$.

Luomala E-M., Juhanoja S., Lukkala R., Jaakkola E., Nykänen P. \& Vuorinen L. 2008 Julkisten alueiden perennat -hankkeessa vanhoja kotimaisia perennakantoja. In: Merja Veteläinen (toim.). Suomen Kansallinen Kasvigeenivaraohjelma suojelutyön tukena 2003-2008. MTT:n selvityksiä 165: s. 42.

Matsson, S. 2004. High-Value Urban Open Spaces - Dreampark Enköping, Sweden. Acta Hort. 643:161-167.

Pelz, P. 2004. Generous Use of Perennials. Acta Hort. 641:71-77.

Tuhkanen E. 2009. Parhaat perennat tuotantoon. Maaseudun Tiede 66, 2(1.6.2009): 13.

Tuhkanen E. \& Juhanoja S. 2009. Clonal selection of herbaceous perennials for northern urban areas: healthy and hardy with high ornamental value. In: 2nd international conference on landscape and urban horticulture, Bologna (Italy) 9-13- June 2009: book of abstracts. Bologna: University of Bologna, Faculty of Agriculture, Department of Agroenvironmental Science and Technology. p. 61.

Viherympäristöliitto 2008. Viheralan tulevaisuusstrategia 2008. Viherympäristöliitto. $21 \mathrm{~s}$. 